\title{
Flipped Classroom sebagai Pendekatan Pembelajaran Matematika di Era Pandemi
}

\author{
Yoka Agry Sativa ${ }^{* 1}$, Anggun Badu Kusuma ${ }^{2}$ \\ ${ }^{1,2}$ Universitas Muhammadiyah Purwokerto \\ e-mail: ${ }^{* 1}$ yagry30@yahoo.com, ${ }^{2}$ anggun.badu@gmail.com
}

\begin{abstract}
Abstrak
Saat ini, guru dan siswa menghadapi banyak tantangan ketika belajar matematika. Dalam flipped classroom, kegiatan pembelajaran yang biasanya dilakukan di dalam kelas dilakukan di luar kelas. Oleh karena itu, kegiatan kelas dapat berfokus pada kegiatan yang merangsang siswa untuk berpikir pada tingkat yang lebih tinggi. Metode desain kelas terbalik ini perlu membuatnya memiliki nilai lebih dalam desain pembelajaran. Artikel ini akan mengulas literatur tentang pembelajaran matematika kelas terbalik. Secara khusus, artikel ini akan mengulas definisi dan desain flipped classroom, serta tantangan implementasinya. Artikel ini akan mengulas desain dan implementasi penelitian kelas terbalik dalam pembelajaran matematika, dan memberikan beberapa saran bagi guru dan praktisi tentang penerapan kedua strategi pembelajaran tersebut.
\end{abstract}

Kata Kunci : Flipped Classroom, Pembelajaran Matematika, Pandemi, Daring

\section{PENDAHULUAN}

Definisi pandemi menurut WHO adalah "Epidemi yang terjadi di seluruh dunia, atau di wilayah yang sangat luas, melintasi batas internasional dan biasanya mempengaruhi sejumlah besar orang" (Kurniawati, Santanapurba, \& Kusumawati, 2019). Situasi tak terduga berupa wabah penyakit Covid-19 telah membawa perubahan. Perkembangan virus dengan cepat menyebar ke seluruh penjuru dunia. Setiap hari di dunia, ada data yang mengumumkan bahwa cakupan dan pengaruh Covid-19 semakin meningkat. Indonesia juga sedang dalam keadaan darurat nasional. Kematian akibat korona terus berlanjut sejak pertama kali diumumkan bahwa seseorang dinyatakan positif mengidap virus Covid-19, awal Maret 2020. Hal ini mempengaruhi perubahan dan pembaruan kebijakan baru yang juga muncul di bidang pendidikan. Pemerintah menganjurkan untuk tinggal di rumah, menjaga jarak dan harus mengikuti pembelajaran secara online.

Teknologi Informasi dan Komunikasi (TIK) adalah teknologi yang berhubungan dengan pengambilan, pengumpulan, pengolahan, penyimpangan, penyebaran, dan penyajian informasi. Pentingnya keterampilan komunikasi, kolaborasi, dan literasi TIK kepada siswa dapat dijadikan acuan bagi guru untuk merencanakan dan melaksanakan pembelajaran matematika yang berkualitas. Untuk tujuan ini, pembelajaran matematika seharusnya tidak hanya membantu siswa belajar matematika dengan memahami dan mengkonstruksi pengetahuan baru dari pengalaman dan pengetahuan sebelumnya (NCTM, 2000), tetapi juga menyediakan lingkungan belajar bagi siswa untuk meningkatkan komunikasi dan komunikasi mereka melalui pembelajaran berkomunikasi. Keterampilan kolaborasi. Pemanfaatan teknologi informasi dan komunikasi. Untuk itu, guru harus dapat memilih model pembelajaran yang memungkinkan siswa berpartisipasi aktif dalam proses komunikasi dan kolaborasi, serta meningkatkan pemahaman siswa terhadap ide-ide matematika melalui pemanfaatan teknologi (Martin, 2007).

Flipped classroom dapat digunakan sebagai metode pembelajaran bagi guru untuk meningkatkan kemampuan teknis siswa. Dengan menggunakan flipped classroom, siswa dapat mengembangkan kemampuannya dalam menggunakan teknologi sambil belajar. Tidak hanya itu, flipped classroom juga

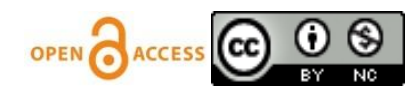


dapat dapat menumbuhkan kemampuan berpikir tingkat tinggi (Lai \& Hwang, 2016). Cara ini tersebut cocok digunakan di era pandemi saat ini, era tersebut menggunakan teknologi digital, dan bersifat online. Perlu diterapkan model pembelajaran yang lebih bermakna dan tepat di kelas untuk menumbuhkan kemampuan berpikir kritis siswa. Salah satu wujud pembelajaran yang berpusat pada siswa itu sendiri adalah adanya blended learning, yaitu suatu bentuk pembelajaran yang menggabungkan pembelajaran tatap muka dan pembelajaran online. Guru diharapkan mampu untuk menciptakan metode pembelajaran yang dapat membuat siswa menjadi efektif dalam menerima pelajaran yang disampaikan (Maolidah, Ruhimat, \& Dewi, 2017). Salah satu metode pembelajaran yang berpusat pada siswa yaitu flipped classroom (Kurniawati, Santanapurba, \& Kusumawati, 2019).

Pandemi Covid-19 telah menyebabkan perubahan yang luar biasa, termasuk di bidang pendidikan. Seolah-olah semua jenjang pendidikan "dipaksa" untuk beralih secara tiba-tiba dan menyeluruh beradaptasi dengan pembelajaran di rumah melalui media online. Ini tentu bukan tugas yang mudah, karena belum sepenuhnya siap. Permasalahan dalam pendidikan adalah proses pembelajaran yang tidak seragam, baik itu standar maupun kualitas hasil belajar yang diharapkan. Matematika pada dasarnya merupakan ilmu yang banyak digunakan dalam bidang keilmuan lainnya, baik itu dalam cakupan bilangan, aljabar, geometri, data dan probabilitas. Oleh karena itu, perlu diadopsi berbagai metode untuk mengajarkan matematika kepada siswa, yang tentunya harus memenuhi kebutuhan siswa dan kebutuhan perkembangan teknologi informasi. Pada artikel ini, penulis secara teoritis akan menyelidiki peluang penerapan kelas terbalik dalam pembelajaran matematika.

\section{METODE PENELITIAN}

Metode penelitian yang digunakan dalam artikel ini adalah studi pustaka. Artikel ini diperoleh dari kumpulan bahan referensi yang berasal dari catatan, hasil penelitian, buku, jurnal terkait flipped classroom. Metode analisis pengetahuan menjadikannya sebuah artikel literature review yang sejalan dengan situasi pandemi saat ini. Di masa pandemi saat ini, flipped classroom dapat dijadikan sebagai media pembelajaran alternatif. Penulis telah mengkaji hasil dari penelitian yang diubah menjadi suatu pikiran atau gagasan mengenai flipped classroom dalam pembelajaran matematika di era pandemi saat ini.

\section{HASIL DAN PEMBAHASAN}

Dalam prosesnya Flipped Classroom menjadi salah satu pendekatan yang menarik perhatian para peneliti, akademisi dan guru. Hal ini sesuai dengan laporan Hwang et al.(2019) yang menyatakan adanya kenaikan penelitian terhadap Flipped Classroom. Beragam definisi telah ditawarkan untuk pendekatan yang sering disebut dengan Flipped Learning dan Inverted Classroom dari penelitian-penelitian yang sudah ada. Terdapat dua definisi yang sering digunakan untuk mendefinisikan pendekatan Flipped Classroom yaitu yang diajukan oleh Flipped Learning Network (FLN, 2014).

Flipped classroom didefinisikan sebagai strategi pembelajaran yang terdiri dari dua bagian, yaitu kegiatan pembelajaran kelompok interaktif di dalam kelas, dan pengajaran komputer langsung yang dilakukan secara terpisah dan di luar kelas Bishop \& Verleger (2013). Definisi ini secara jelas membedakan kegiatan yang dilakukan siswa di dalam dan di luar kelas. Secara garis besar, kegiatan pembelajaran yang dilakukan siswa di dalam kelas adalah pembelajaran kelompok. Selain itu, pembelajaran di kelas bersifat interaktif. Artinya, flipped classroom lebih menekankan pada interaksi antar pelaku pembelajaran. Sebaliknya, kegiatan belajar di luar kelas lebih menekankan pada pembelajaran langsung dalam keterasingan. Kegiatan ekstrakurikuler semacam ini didukung oleh komputer dan berfungsi sebagai media transmisi informasi pembelajaran. Media berbasis komputer yang digunakan dalam kegiatan ekstrakurikuler adalah video pembelajaran.

Model Flipped Classroom memiliki keterkaitan dengan Taksonomi Bloom. Pada ranah kognitif Taksonomi Bloom memiliki enam kategori dari paling rendah ke tinggi yaitu pengetahuan, pemahaman, penerapan, analisis, sintesis dan evaluasi. Hal ini sesuai dengan pendapat Adhitya (2015) yang menyatakan 
https://jurnal.unsulbar.ac.id/index.php/saintifik

pembelajaran konvensional kategori pengetahuan dan pemahaman berlangsung di dalam kelas, sedangkan kategori penerapan, analisa, evaluasi, dan mencipta dicapai melalui pekerjaan rumah. Tetapi, jika mengerjakan pekerjaan dirumah tujuan tersebut tidak mudah tercapai karena siswa akan berhenti jika menemui hambatan. Dalam pendekatan pembelajaran flipped classroom kategori pengetahuan dan pemahaman dapat diberikan guru melalui video untuk pembelajaran dirumah, sedangkan kategori penerapan, analisa, evaluasi, dan mencipta dapat diberikan saat pembelajaran berlangsung oleh guru didalam kelas. Ranah kognitif Taksonomi Bloom menurut Adhitya (2015) Lower Order Thinking Skill merupakan tingkatan dari pengetahuan, pemahaman dan penerapan sedangkan Higher Order Thinking Skill merupakan tingkatan dari analisa, evaluasi, dan mencipta. Sedangkan, kemampuan pemecahan masalah merupakan salah satu Higher Order Thingking Skill (Adhitya, 2015).

Untuk mengimplementasikan pendekatan flipped learning seperti yang didefinisikan oleh FLN (2014) tersebut, guru harus menggabungkan empat pilar pendekatan pembelajaran tersebut, yaitu : (1) Lingkungan belajar yang fleksibel, (2) budaya belajar yang berpusat pada siswa, (3) isi pembelajaran yang direncanakan, (4) guru yang profesional. Dengan lingkungan belajar yang fleksibel, siswa dapat memperoleh berbagai cara belajar, serta dapat memilih waktu dan tempat belajar. Budaya pembelajaran dalam metode flipped learning harus berubah dari pembelajaran yang berpusat pada guru menjadi pembelajaran yang berpusat pada siswa. Dengan budaya ini, siswa akan menggunakan waktu kelas untuk mengeksplorasi topik secara mendalam dan mendapatkan kesempatan belajar yang lebih kaya. Selain itu, guru harus memilih dan memilah konten pembelajaran mana yang akan diajarkan secara langsung dan konten mana yang akan ditempatkan dalam lingkungan pembelajaran pribadi. Pada pilar terakhir, guru harus profesional. Artinya, peran guru tidak dapat digantikan dengan pembelajaran terbalik, tetapi dibandingkan dengan pembelajaran tradisional, peran guru dalam metode ini menjadi semakin penting.

Tambahan waktu menjadi alasan utama implementasi flipped classroom yang membuat aktivitas pembelajaran didalam kelas yang dapat difokuskan untuk pembelajaran yang berpusat pada siswa. Flipped classroom dapat menerapkan teori pembelajaran berpusat pada siswa (student-centered learning). Koh (2019) menyatakan bahwa ada empat dimensi pedagogis yaitu personalisasi, berpikir tingkat tinggi (higherorder thinking), pengarahan diri sendiri (self-direction), dan kolaborasi menjadi empat dimensi pedagogis untuk menjelaskan alasan flipped classroom dapat mendukung pembelajaran yang berpusat pada siswa.

Fleksibilitas dan pilihan terkait aktivitas dan sumber belajar merupakan ususlan yang sesuai dengan dimensi personalisasi teori pembelajaran yang berpusat pada siswa (Neumann, 2013). Guru di tuntut untuk memberikan dukungan terhadap kebutuhan individu siswa yang dapat dilihat dari aktivitas pembelajaran didalam kelas flipped calssroom. Model pembelajaran yang berbeda dan dilakukan sesuai dengan waktu dan tempat yang dipilih sendiri menjadi kesempatan untuk belajar dengan pendekatan ini.

Seharusnya pembelajaran yang mendalam dan konstruktif menjadi dimensi berpikir tingkat tinggi dalam teori pembelajaran yang berpusat pada siswa (Lea et al., 2003). Mengembangkan keterampilan berpikir tingkat tinggi atau berpikir kritis siswa melalui aktivitas pemecahan masalah merupakan dimensi yang nampak pada aktivitas pembelajaran flipped classroom. Penerapan pengetahuan dan pemahaman yang digunakan untuk memecahkan permasalahan sehari-hari merupakan kesempatan aktivitas pemecahan masalah.

Siswa dituntut oleh dimensi pengarahan diri sendiri untuk bertanggung jawab dan otonom terhadap pembelajarannya sendiri. Pendekatan flipped classroom nampak menuntut siswa untuk mempelajari materi pembelajaran misalnya dengan menonton video sebelum kelas dimulai dan bertanggung jawab terhadap pembelajarannya sendiri. O'Flaherty \& Phillips (2015) menyatakan bahwa flipped classroom membuat siswa mempersepsi dirinya sebagai pelajar yang mandiri sebagai bukti literatur.

Pembelajaran kolaboratif memungkinkan diterapkannya dalam proses pembelajaran flipped classroom. Pengetahuan pendekatan memberikan ruang bagi siswa untuk membangun pengetahuannya di dalam konteks sosisal bersama dengan teman dan guru. Dampak pembelajaran seperti ini hanya bagi perkembangan pengetahuan dan pemahaman siswa dan juga motivasi intrinsik siswa berpengaruh terhadap kebutuhan akan relasinya terpenuhi (Deci \& Ryan, 2000). 
Flipped classroom sudah disebutkan sebelumnya bahwa pendekatan pembelajaran yang menarik perhatian guru terutama dalam pembelajaran matematika. Penelitian sudah dilakukan oleh banyak ahli dalam pembelajaran matematika atau di dalam perkuliahan terhadap implementasi flipped classroom. Dalam pembelajaran matematika implementasi flipped classroom ditemukan di literatur yang bervariasi. Pemanfaatan video untuk aktivitas pembelajaran di luar kelas merupakan salah satu variasi dari pendekatan tersebut. Pemanfaatan video yang sudah ada dan memproduksi sendiri video untuk siswanya digunakan oleh guru dalam pembelajaran (Kristanto \& Padmi, 2019; Scott et al., 2016). Siswa diberikan tugas dari buku teks, lembar kerja, kuis daring, dan sumber lainnya sebagai penunjang pembelajaran selama menonton video.

Aktivitas pembelajaran di dalam kelas juga menjadi variasi implementasi flipped classroom pada pembelajaran matematika. Penilaian formatif untuk memulai kegiatan pembelajaran tatap mukanya juga digunakan oleh beberapa guru. Selama kegiatan pembelajaran di dalam kelas kebanyakan guru menggunakan metode pembelajaran kelompok. Pengajaran antar teman dan pembelajaran kooperatif menjadi metode kelompok yang digunakan. Di akhir kegiatan tatap muka flipped classroom juga dilakukan kuis, tugas individu, dan presentasi. Hasil belajar, sikap, motivasi, antisipasi usaha, kepuasan, dan minat menjadi efektivitas flipped classroom dalam pembelajaran matematika yang sudah ditinjau dari berbagai sudut pandang (Yang et al., 2019).

Flipped classroom memberikan manfaat bagi proses belajar siswa di kelas dalam pembelajaran matematika menjadi dua penelitian kajian pustaka. Manfaat yang dihasilkan oleh flipped classroom ini disebabkan oleh tiga hal, yaitu (1) cukupnya waktu untuk pengerjaan tugas, (2) pengintegrasian pengetahuan baru dengan pengetahuan yang sudah ada, dan (3) umpan balik yang cepat.

Fasilitasi pembelajaran yang berpusat pada siswa sudah disediakan oleh pendekatan pembelajaran flipped classroom. Dengan pendekatan ini, siswa dituntut untuk bertanggung jawab terhadap pembelajaran mereka sendiri di luar kelas. Belajar secara otonom melalui video-video pembelajaran di dalam kelas merupakan cara mereka mewujudkan potensi pembelajaran flipped classroom. Mereka akan siap melakukan pembelajaran di dalam kelas dengan cara seperti itu. Sebelum masuk kelas siswa telah menyiapkan persiapan, maka waktu di dalam kelas dapat dioptimalkan dengan pembelajaran aktif dan inovatif, seperti diskusi, pemecahan masalah, presentasi, ataupun pembelajaran berbasis proyek.

Flipped classroom menawarkan konsep pembelajaran yang berpusat pada siswa tetapi harus didukung oleh kemauan siswa untuk belajar. Dengan kata lain, siswa harus memiliki motivasi yang tinggi untuk mengikuti keseluruhan tahapan flipped classroom, mulai dari menonton video pembelajaran di luar kelas, berdiskusi menyelesaikan masalah di dalam kelas, dan mengerjakan tugas atau proyek yang diberikan. Sehingga sangat penting bagi guru dan desainer pembelajaran untuk menyediakan mekanisme yang dapat menjamin tetap tingginya motivasi belajar siswa tersebut.

Hung et al. (2019) Menerapkan flipped classroom ke pembelajaran berbasis permainan, memungkinkan siswa dari jenis kelamin yang berbeda, kelas yang berbeda dan percaya diri dalam matematika untuk bermain game. Sebelum memasuki kelas, siswa diminta untuk menonton video pembelajaran dan praktik. Saat menonton video, siswa dapat memahami tingkat partisipasi dan kemampuan melalui poin-poin yang ditampilkan. Tujuan dari latihan adalah agar siswa memahami perkembangan kemampuannya dalam mempelajari materi. Di dalam kelas, siswa dibiasakan dengan pembelajaran berbasis game. Di kelas ini, semua siswa dibagi menjadi beberapa kelompok yang heterogen, terdiri dari 3 sampai 4 siswa. Setiap siswa dalam kelompok diberi peran sebagai jenderal, ahli taktik, dan prajurit. Penugasan peran ini didasarkan pada kemampuan matematika siswa, jenderal untuk siswa berkemampuan tinggi, ahli taktik untuk siswa berkemampuan menengah, dan tentara untuk siswa berkemampuan rendah. Mendiskusikan dan menyelesaikan permasalahan matematika yang diperoleh dari buku teks ataupun video pembelajaran yang telah mereka tonton merupakan tugas masing-masing kelompok. Menaklukan wilayah dari peta yang diberikan guru (hal ini merupakan elemen cerita dalam gim tersebut) termasuk dengan penyelesaian masalah yang digunakan. Setelah kelompok selesai menyelesaikan permasalahannya, mereka diminta untuk menunjuk salah satu anggota kelompok untuk mempresentasikannya. Jika seorang jenderal 
mempresentasikannya, maka nilai kelompoknya adalah 1 poin, jika ahli taktik nilainya 2 poin, dan jika prajurit nilainya adalah 3 poin.

Menurut (Baker, 2000) komponen online untuk pekerjaan di luar kelas dan perubahan yang terjadi di dalam kelas merupakan dua komponen pelaksanaan flipped classroom. Materi pelajaran yang disajikan secara online merupakan hal pertama dalam komponen online untuk pekerjaan di luar kelas. Berbagai software dapat dimanfaatkan dan dapat dimonitoring langsung oleh guru. Pelaksanaan grup diskusi yang berlangsung secara online merupakan komponen kedua, dimana siswa berpeluang untuk lebih interaktif dalam berdiskusi online dibandingkan dengan diskusi di kelas. Yang terakhir yaitu pelaksanaan kuis, dimana materi pelajaran yang mereka baca secara online dalam rangka mempersiapkan pelajaran di dalam kelas. Sementara itu, pembelajaran di kelas dilaksanakan dengan menggunakan "active learning". Dimana pembelajaran dilaksanakan dengan pendekatan : 1) Clarify, 2) Expand-next, 3) Aplly-one, 4) Practice.

Smallhorn (2017) menyampaikan bahwa ada pedagogi pembelajaran aktif (active learning pedagogy) yang didasarkan pada model flipped classroom. Senada dengan hal tersebut pembelajaran flipped classroom di dalam kelas diawali dengan berdiskusi tentang video yang telah ditonton siswa pada malam sebelumnya, bisa dalam bentuk pertanyaan-pertanyaan mengenai materi yang dicatat oleh siswa (Bergmann \& Sams, 2012). Meluruskan miskonsepsi yang mungkin dilakukan siswa menjadi kesempatan guru pada kegiatan ini. Kegiatan laboratorium maupun tes akan diberikan kepada siswa sebagai aktivitas pemecahan masalah terarah.

Sementara itu (Adhitiya, Prabowo, \& Arifudin, 2015) membagi model flipped classroom menjadi dua jenis, yaitu flipped classroom tradisional dan flipped peer teaching. Pada dasarnya kedua jenis tersebut dimulai dari menonton video pembelajaran atau media lain di rumah, namun perbedaannya terletak pada aktivitas di dalam kelas. Pembelajaran flipped classroom tradisional dipandu oleh lembar kerja, sedangkan flipped peer teaching dilakukan seperti pembelajaran tutor sebaya. Pada saat yang sama, pandangan lain membagi flipped classroom menjadi tiga bagian utama, yaitu kegiatan prasekolah, kegiatan pertengahan sekolah, dan kegiatan penutup (Çetinkaya, 2017). Dalam kegiatan prasekolah, siswa diharuskan menonton video dan berpartisipasi dalam pembelajaran mandiri berbasis jaringan. Saat belajar di dalam kelas, kegiatan pembelajaran didasarkan pada jaringan. Di akhir kursus, penilaian dan evaluasi berbasis web akan dilakukan.

Berdasarkan pemaparan proses pembelajaran flipped classroom tersebut, maka perlu diingat bahwa sebelum menerapkan pembelajaran ini, perlu dipersiapkan rencana yang matang. Miller dalam (Yildirim \& Kiray, 2016) menyatakan terdapat lima faktor yang harus diperhatikan dalam mempersiapkan pembelajaran ini, yaitu : 1) Meaningfull content, 2) Attention grabbing models, 3) Technology, 4) Reflection, 5) Time and place.

Meskipun banyak penelitian melaporkan dampak positif dari pendekatan flipped classroom pada pembelajaran siswa, beberapa penelitian melaporkan hasil yang berbeda. Misalnya, kepuasan siswa terhadap metode pembelajaran sedang menurun. Sejumlah penelitian menunjukkan bahwa tidak ada perbedaan hasil belajar yang signifikan antara siswa di kelas terbalik dan pembelajaran tradisional.

Selain yang telah disebutkan sebelumnya, tantangan-tantangan lainnya implementasi flipped classroom adalah tantangan-tantangan terkait siswa (Lo et al., 2017). Tantangan yang terkait dengan siswa ini antara lain siswa tidak terbiasa dengan flipped classroom, persiapan yang tidak memadai untuk tugas prasekolah, ketidakmampuan untuk mengajukan pertanyaan dalam kegiatan pembelajaran di luar kelas, ketidakmampuan untuk memahami konten video, peningkatan beban belajar, dan kurangnya minat menonton video. Selain itu, tantangan lain yang dihadapi ketika menerapkan flipped classroom adalah siswa kurang memiliki motivasi untuk berpartisipasi penuh dalam kegiatan pembelajaran di luar kelas. Sejumlah penelitian menemukan bahwa tidak semua siswa akan memperoleh materi pembelajaran dalam kegiatan pra sekolah dan pasca sekolah. Jika siswa tidak mengakses materi pembelajaran yang disediakan, hasil belajar siswa tersebut seringkali tidak lebih baik daripada siswa kelas tradisional (Lai \& Hwang, 2016).

Tantangan penerapan flipped classroom yang disebutkan di atas perlu diatasi melalui penggunaan strategi inovatif. Masalah kurangnya motivasi dalam kegiatan belajar sebelum dan sesudah partisipasi dapat diatasi dengan memberikan insentif (Kim et al., 2014). 
https://jurnal.unsulbar.ac.id/index.php/saintifik

Ada banyak keuntungan dari flipped classroom. Menurut (Bergmann \& Sams, 2012), berikut adalah alasan mengapa guru harus mempertimbangkan pembelajaran flipped classroom : 1) mengikuti perkembangan zaman siswa, 2) membantu siswa yang sibuk, 3) membantu siswa yang mengalami kesulitan, 4) membantu siswa yang mampu. siswa memahami materi yang lemah, 5) diperbolehkan untuk berhenti dan mengulang penjelasan guru melalui video, 6) untuk memperkuat interaksi antara siswa dan guru, 7) agar guru dapat lebih mengenal siswanya, 8) untuk memperkuat interaksi antara siswa dan siswa, 9) Meningkatkan pengelolaan kelas, 10) Mengubah cara berinteraksi dengan orang tua, 11) Membuat kelas lebih transparan, 12) Keterampilan yang baik untuk guru yang tidak hadir.

Selain itu menurut (Yildirim \& Kiray, 2016), kelebihan dari penerapan flipped classroom ini adalah sebagai berikut : 1) Siswa dapat menghabiskan lebih banyak waktu dengan menggunakan peralatan ilmiah yang hanya dapat digunakan di kelas, 2) Siswa dapat terus belajar meskipun tidak di kelas, 3) Mendorong siswa untuk berpikir dan belajar di dalam dan di luar kelas, 4) Siswa berubah dalam proses pembelajaran Menjadi lebih aktif, 5) Karena siswa menjadi aktif dalam belajar, yang membuat mereka menyukai pekerjaan yang mereka lakukan.

Namun dibalik keunggulan dari flipped classroom, kelemahan dari pembelajaran ini yang mungkin dapat diantisipasi oleh guru menurut (Yildirim \& Kiray, 2016) adalah : 1) Dalam proses pembuatan konten video, sebagian besar waktu guru tersita, 2) Jika guru tidak dapat berinteraksi secara aktif dengan siswa di luar kelas, maka akan mempengaruhi motivasi belajar siswa, 3) Bagi yang terbiasa model pembelajaran tradisional, siswa mungkin ada beberapa masalah saat beradaptasi dengan modus pembelajaran baru ini 4) Video yang dibuat oleh guru dapat membuat siswa sulit memahami materi.

Selain itu juga ada beberapa kelemahan dari flipped classroom ini (Yildirim \& Kiray, 2016), yaitu: 1) Sulit bagi guru untuk menentukan apakah siswa telah menonton video Pembelajaran atau tidak, 2) Siswa yang tidak memiliki kemampuan dalam menggunakan pembelajaran flipped classroom akan kesulitan untuk mengikuti kegiatan pembelajaran, 3) Membutuhkan akses komputer dan internet, yang akan mempersulit pelaksanaan flipped classroom, 4) membutuhkan banyak dana, 5) pembelajaran melalui video Siswa yang tidak bertanya akan kesulitan menjalin hubungan antar topik. Oleh karena itu, tanpa komputer dan koneksi internet, belajar akan sulit.

\section{KESIMPULAN}

Berdasarkan karakteristik model pembelajaran flipped classroom dapat membantu siswa belajar di dalam dan di luar kelas, memungkinkan siswa berpartisipasi langsung dalam proses pembelajaran. Dengan berkembangnya teknologi informasi, guru menggunakan teknologi dalam pembelajaran berdasarkan karakteristik matematika Keberanian untuk berinovasi dan berinovasi dalam metode pembelajaran, model pembelajaran flipped classroom ini berpotensi untuk diterapkan dalam pembelajaran matematika.

\section{DAFTAR PUSTAKA}

Adhitiya, E. N., Prabowo, A., \& Arifudin, (2015). Studi komparasi model pembelajaran traditional flipped classroom dengan peer instruction flipped terhadap kemampuan pemecahan masalah. Unnes Journal ofMathematics Education, 4(2), 116- 126.

Baker, J. W. (2000). The" classroom flip":Using web course management toolsto become the guide by the side. In Selected Papers From the 11Th International Conference on CollegeTeaching and Learning (pp. 9-17).

Bergmann, J., \& Sams, A. (2012). Flip yourclassroom reach every student in every class every day (First Edition). United States of America: iste. https://doi.org/10.1111/teth.12165

Bishop, J. L., \& Verleger, M. A. (2013). The flipped classroom: A survey of the research. Paper presentedat the 120th American society of engineering education (ASEE) annual conference \& exposition. Atlanta, GA. 
https://jurnal.unsulbar.ac.id/index.php/saintifik

Çetinkaya, M. (2017). Designing and applying web assisted activities to beused in flipped classroom model. International Journal of Evaluationand Research in Education, 6(2), 128-137.

Deci, E. L., \& Ryan, R. M. (2000). The "what" and "why" of goal pursuits: Human needs and the selfdetermination of behavior. Psychological inquiry, 11(4), 227-268.

FLN. 2014. Definition of Flipped Learning. (Online). (https://flippedlearning.org/definition-offlippedlearning/, diakses 19 Oktober 2019)

Hung, C. Y., Sun, J. C. Y., \& Liu, J. Y. (2019). Effects of flipped classrooms integrated with MOOCs and game-based learning on the learning motivation and outcomes of students from different backgrounds.Interactive Learning Environments, 27(8), 1028-1046.

Hwang, G.-J., Yin, C., \& Chu, H.-C. (2019). The era of flipped learning: promoting active learning and higher order thinking with innovative flipped learning strategies and supporting systems. Interactive Learning Environments, 27(8), 991-994.

Kim, M. K., Kim, S. M., Khera, O., \& Getman, J. (2014). The experience of three flipped classrooms in an urban university: an exploration of design principles. The Internet and Higher Education, 22, 37-50.

Koh, J. H. L. (2019). Four pedagogical dimensions for understanding flipped classroom practices in higher education: A systematic review. Educational Sciences: Theory \& Practice, 19(4), 14-33.

Kristanto, Y. D., \& Padmi, R. S. (2019). Flipping A Statistics Classroom for Pre-Service English Language Teachers. In Proceeding of the $62^{\text {nd }}$ ISI World Statistics Congress 2019. Kuala Lumpur.

Kurniawati, M., Santanapurba, H., \& Kusumawati, E. (2019). Penerapan Blended Learning Menggunakan Model Flipped Classroom Berbantuan Google Classroom Dalam Pembelajaran Matematika Smp. EDU-MAT: Jurnal Pendidikan Matematika, 7(1), 8-19. https://doi.org/10.20527/edumat.v7i1.6827

Lai, C.-L., \& Hwang, G.-J. (2016). A self-regulated flipped classroom approach to improving students' learning performance in a mathematics course. Computers \& Education, 100, 126-140.

Lea, S. J., Stephenson, D., \& Troy, J. (2003). Higher education students' attitudes to student-centred learning: beyond 'educational bulimia'? Studies in higher education, 28(3), 321-334.

Lo, C. K., \& Hew, K. F. (2017). A critical review of flipped classroom challenges in K-12 education: Possible solutions and recommendations for future research. Research and Practice in Technology Enhanced Learning, 12(1), 4.

Lo, C. K., Hew, K. F., \& Chen, G. (2017). Toward a set of design principles for mathematics flipped classrooms: A synthesis of research in mathematics education. Educational Research Review, 22, 5073.

Maolidah, I. S., Ruhimat, T., \& Dewi, L. (2017). Efektivitas Penerapan Model Pembelajaran Flipped CLASSROOM PADA PENINGKATAN KEMAMPUAN BERPIKIR KRITIS SISWA.

Edutcehnologia, 3(2), 160-170.

https://ejournal.upi.edu/index.php/edutechnologia/article/view/9147/5684

Martin, T. S. (2007). Mathematics Teaching Today: Improving Practice, Improving Student Learning. Reston, VA: The National Council of Teachers of Mathematics, Inc.

NCTM. (2000). Principles and Standards for School Mathematics. Reston, VA: The National Council of Teachers of Mathematics, Inc.

Neumann, J. W. (2013). Developing a New Framework for Conceptualizing "Student-Centered Learning. "The Educational Forum, 77(2), 161-175.

O'Flaherty, J., \& Phillips, C. (2015). The use of flipped classrooms in higher education: A scoping review. The internet and higher education, 25, 85-95.

Smallhorn, M. (2017). The flipped classroom: A learning model to increase student engagement notacademic achievement. Student Success, 8(2), 43-53.

Yang, Q.-F., Lin, C.-J., \& Hwang, G.-J. (2019). Research focuses and findings of flipping mathematics classes: a review of journal publications based on the technology-enhanced learning model. InteractiveLearning Environments, 1-34.

Yildirim, F. S., \& Kiray, S. A. (2016). Flipped classroom model in education. Research Highlights in Education and Science, 2, 1-8. 